\title{
Development of social-ecological conceptual models as the basis for an integrated ecosystem assessment framework in Southeast Alaska
}

\author{
$\underline{\text { Judith Rosellon-Druker }}^{1}$, Marysia Szymkowiak $^{2}, \underline{\text { Curry J. Cunningham }}^{2}, \underline{\text { Stephen Kasperski }}^{2}, \underline{\text { Gordon H. Kruse }}^{1}, \underline{\text { Jamal H. Moss }}^{2}$ \\ and Ellen M. Yasumiishi ${ }^{2}$
}

\begin{abstract}
Integrated ecosystem assessment (IEA) is a framework that organizes and summarizes science to aid in the transition from a traditional single sector toward a holistic management approach known as ecosystem-based management (EBM). An essential step of the IEA framework is the development of conceptual models. These models allow the integration of intrinsically linked social, environmental, and biological components of marine ecosystems that is pivotal to address unsolved questions in fisheries management. We constructed social-ecological conceptual models of relevant commercial and subsistence fisheries for Sitka, a fisheries-based community in Southeast Alaska, by collecting and synthesizing available scientific information, local ecological knowledge (LEK), and qualitative information. We conducted focus groups with key informants in Sitka who had in-depth knowledge of their community's interactions with local fisheries and the structure and function of the surrounding ecosystem. The resulting conceptual models coproduced by scientists and Sitka stakeholders, illustrate the main biological and environmental factors driving the abundance of Pacific halibut (Hippoglossus stenolepis) and Pacific herring (Clupea pallasii) in Southeast Alaska. Furthermore, these coproduced models elucidate how the interaction between Sitka residents and these fisheries affect community well-being. Our models will serve as the basis to assess EBM objectives for Sitka as part of an IEA place-based framework. This study also highlights the importance of integrating LEK into science and potentially into the broader Alaska fisheries management structure.
\end{abstract}

Key Words: fisheries management; human well-being; local ecological knowledge; participatory methods; place-based IEA; stakeholder input

\section{INTRODUCTION}

For the past several decades there has been growing realization among managers, scientists, and stakeholders of the need to expand fisheries management beyond single-species considerations. The rationale for this wider approach stems in part from poor performance of single-species management in many fishery systems worldwide (Pikitch et al. 2004), but more broadly includes a general appreciation for the importance of socio-economic components, climate, species interactions, and the direct and indirect effects of fishing on target species, bycatch species, and habitats. Ecosystem-based fisheries management (EBFM) endeavors to manage fisheries in a manner that addresses the multiple objectives of stakeholders without jeopardizing options of future generations to benefit from the full range of ecosystem goods and services (Marasco et al. 2007). More broadly, ecosystem-based management (EBM) is an interdisciplinary approach that balances ecological, social, and governance principles at appropriate temporal and spatial scales to achieve sustainable resource use (Long et al. 2015). EBM considers humans as part of a unified system that addresses all sectors including fisheries and other ecosystem services, while incorporating cross-sector trade-offs (Link and Browman 2014).

In recent years, national and international intergovernmental and marine science organizations have moved toward the implementation of integrated ecosystem assessments (IEAs) to support EBM (ICES 2017). IEAs are a critical framework intended to organize science to inform decisions in EBM at multiple scales and across different sectors (Levin et al. 2009). IEAs function to evaluate ecosystem status with respect to stated objectives while accounting for holistic impacts of management decisions, and help to guide the evaluation of management alternatives (Levin et al. 2009). Although IEAs were developed to be multisectoral, the process can be adopted for sector-specific applications such as fisheries (Link and Browman 2014). Placebased and species-specific IEAs have also been established within IEAs that span a larger geographic scale. For example, smaller place-based IEAs established along the West Coast of North America such as the Monterey Bay and Channel Islands National Marine Sanctuaries are located within the California Current Integrated Ecosystem Assessment (CCIEA; Breslow et al. 2016). Levin et al. (2009) outlined a five-step process for IEAs, as shown in the National Oceanic and Atmospheric Administration (NOAA) IEA loop (Fig. 1): (1) scoping to identify specific ecosystem objectives and threats, (2) indicator development where appropriate indicators of ecosystem status are identified and validated, (3) risk analysis to evaluate the risk to indicators posed by human activities and natural processes, (4) management strategy evaluation using an ecosystem modeling approach to evaluate the potential for different management actions to affect the status of natural and human system indicators, and (5) continued monitoring and evaluation of ecosystem indicators.

An essential part of the first stage (scoping) of the IEA loop is the development of conceptual models. Conceptual models are representations of systems that allow the integration of intrinsically linked social, environmental, and biological components (Levin et al. 2016a, Zador et al. 2017). By incorporating and synthesizing information across a wide array of disciplines and sources, conceptual models have become an essential tool for identifying knowledge gaps, informing research needs, and developing EBM objectives and strategies (Harvey et al. 2016, Zador et al. 2017). These models serve to address many questions in fisheries management and aim to ensure that management strategies translate into community well-being (Levin et al. 2009, Levin et al. 2016a). Conceptual models facilitate

${ }^{1}$ College of Fisheries and Ocean Sciences, University of Alaska Fairbanks, ${ }^{2}$ Alaska Fisheries Science Center, National Marine Fisheries Service, National Oceanic and Atmospheric Administration 
the selection of ecological and socio-economic ecosystem indicators, and they emerge as the basis for risk assessments and quantitative ecosystem models (Harvey et al. 2016, Ingram et al. 2018). The importance of properly developed conceptual models not only relies on their effectiveness in capturing the scientific understanding of an ecosystem, but also on their ability to promote engagement by stakeholders and scientists from different backgrounds, allowing the incorporation of diverse types of knowledge into these models (Levin et al. 2016b).

Fig. 1. Five-step process associated with integrated ecosystem assessments (Levin et al. 2009). Conceptual diagram reproduced with permission from National Oceanic and Atmospheric Administration Fisheries.

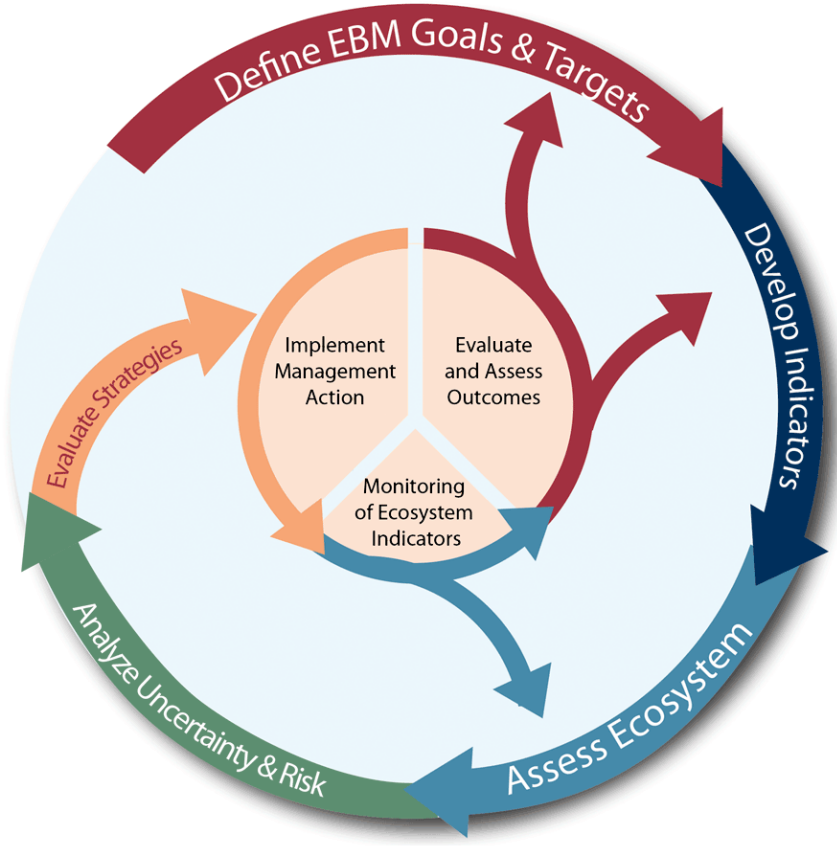

Conceptual models benefit immensely from participatory methods such as collaborative workshops with scientists and local participants, i.e., charter fishing operators, fishermen, fishing industry reps, indigenous people, tourism developers, researchers, etc., who possess a deeper understanding of their local ecosystem based on day-to-day observation and practical experience (Ingram et al. 2018). The incorporation of a place-based or local ecological knowledge (LEK) into science is needed to achieve sustainable, effective, and equitable management of fisheries at local scales (Palacios-Agundez et al. 2013, Raymond-Yakoubian et al. 2017), and can add legitimacy to management decisions (Wasdworth et al. 2014). Olsson and Folke (2001:87) defined LEK as "the knowledge held by a specific group of people about their local ecosystems. It concerns the interplay among organisms and between organisms and the environment. LEK may be a mix of scientific and practical knowledge; it is site-specific and often involves a belief component."

Here we describe the development of conceptual social-ecological models for Southeast Alaska with Pacific halibut (Hippoglossus stenolepis) and Pacific herring (Clupea pallasii) as focal species. These two species are among the most important commercial, recreational, and subsistence fisheries in the Gulf of Alaska (AFSC 2016, Fey et al. 2016). Despite their cultural, ecological, and economic relevance, a description and an understanding of the social-ecological systems surrounding these fisheries, including linkages between human, biological, and environmental components, is lacking, mainly because of the interdisciplinary challenges that these coupled natural-human systems entail. The models presented here were coproduced between scientists from the Alaska Fisheries Science Center (AFSC) of the National Marine Fisheries Service (NMFS) and University of Alaska Fairbanks (UAF) and stakeholders from the Sitka community, who were selected based on their experience and in-depth knowledge of the community's interactions with local fisheries and the surrounding ecosystem. Through data gathered from two participatory workshops and an extensive literature review of ecosystem attributes of the Gulf of Alaska, we characterized the main biological and environmental factors driving the abundance of these species in Sitka. We also identified well-being components associated with subsistence and commercial fisheries use of the focal species, as well as the direction of the linkages between them, to generate the human dimensions components of these models. This study represents a steppingstone for a placedbased IEA framework in Southeast Alaska.

\section{METHODS}

\section{Study site and species selection}

The Gulf of Alaska is a productive large marine ecosystem (LME) with regional gradients in species diversity, abundance, and biomass. In addition to its biological complexity, the eastern and western Gulf of Alaska also differ in their physical properties (Mueter and Norcross 2002, Mundy 2005, Stabeno et al. 2016), effectively partitioning this LME into distinctive ecological subregions. Sitka, a southeastern Alaska community, was selected for the eastern Gulf of Alaska for purposes of conducting a placebased component of the broader Gulf of Alaska IEA. The intent is to conduct similar place-based assessments in other communities that are within the other ecological subregions of the Gulf of Alaska.

Sitka was chosen for development of the first place-based IEA framework based on its geographic location and its relevance for, and reliance on, Alaska's federally managed fisheries. Located on the west coast of Baranof Island (Fig. 2), one of the largest fjord regions of the world (Weingartner et al.2009), Sitka is a diversified and thriving coastal community where commercial, subsistence, and recreational fishing are the most important economic, social, and cultural activities (Himes-Cornell et al. 2013). Sitka's largest economic driver is the seafood industry, which supports seafood processing plants and a robust local commercial fishing fleet (SEDA 2017). Subsistence fisheries represent a way of living for the majority of Sitka residents in terms of food, cultural traditions, and community identity (Sisk 2007, Thorton et al. 2010, Moss et al. 2016). In comparison with other Southeast Alaska fishing communities, Sitka is the most active with respect to the number of active commercial fishing vessels and number of federal and state fishing permits (Fey et al. 2016). Thus, Sitka represents a substantial portion of the total commercial fishing fleet in Southeast Alaska as well as different user groups, but 
future work could expand upon the diversity of communities within this region to move beyond localized value systems.

Fig. 2. Study area. Map showing location of Sitka and Sitka Sound relative to the Gulf of Alaska (GOA) large marine ecosystem.

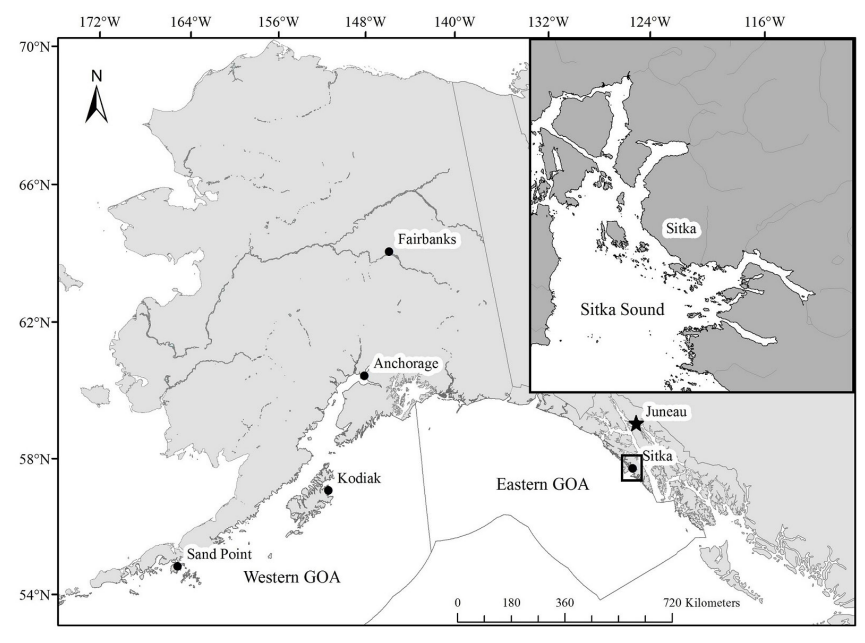

Pacific halibut and Pacific herring are two of the most important commercial and subsistence fisheries for the community of Sitka (AFSC 2016, Fey et al. 2016). For the purposes of this study, the term subsistence is used to encompass all noncommercial fishery harvests by residents of Sitka for the purposes of consumption. Halibut and herring consistently represent two of the most commercially valuable species landed in the community, and halibut is the third most important fishery in terms of the number of Sitka resident-owned vessels participating (AFSC 2016). Halibut is one of the top two subsistence sources of food by weight in the community (Wolfe 2004, Himes-Cornell et al. 2013), and herring is a cultural keystone species for Alaska Natives, prominently incorporated within various oral histories, names, songs, dances, regalia, etc. (Thornton 2015, Thornton and Kitka 2015). Herring roe is particularly prized as food. This subsistence fishery takes place in the spring when female herring deposit their eggs on hemlock branches that are submerged along the shore; these branches are typically cut up and frozen for distribution to elders and families (Wolfe 2004). In 2016, a subsistence fishery for herring spawn in Sitka Sound yielded 38.4 tons, 97\% of which was shared with other households in Sitka and in other communities (Sill and Cunningham 2017).

\section{Building conceptual models}

A research team from NMFS AFSC and UAF, assembled the ecological and environmental aspects of the conceptual models for each focal species by synthesizing available scientific information on the biology and ecology of these species. Literature review started with a bibliographic database search using Internet search engines, i.e., Google Scholar, and the library catalog of University of Alaska system as the main access points. Concomitantly with search engines, we consulted bibliographies in the most updated stock assessments for each focal species as well as any relevant information provided by the Alaska Fisheries Science Center (https://www.afsc.noaa.gov/), the Alaska
Department of Fish and Game (http://www.adfg.alaska.gov/), and the International Pacific Halibut Commission (https://www. iphc.int) web sites. We identified key components within and linkages among environmental and biotic, i.e., main predators, prey, and competitors, components. We documented peer-review or official technical reports for each link: a minimum of one publication was considered sufficient to support a link. A link direction, i.e., positive, negative, or unknown, and a link description, i.e., summary of the interaction, were recorded (Appendices 1, 2). Contrary to what we were expecting, we did not find conflicting link directions among the different references. We prioritized publications where the study site was in or near Sitka Sound or Southeast Alaska, but if no reference was found within this region, we expanded the search to the entire Gulf of Alaska. Environmental variables included oceanographic properties, e.g., sea surface temperature, winds, and freshwater input, and intra-decadal patterns of climate variation, e.g., ENSO, Aleutian low, with a direct effect on the former. From the available literature, the most commonly reported oceanographic properties affecting abundance of the focal species were selected. In the case of the food web relationships, we only included the main four diet components and mortality sources, based on abundance. For model visual simplicity purposes, we aggregated different species within a functional group into a single model node. For example, "marine mammals" or "secondary production" are single nodes that include an array of taxonomically diverse species with a similar ecological function. Appendix 1 contains the expanded version of the different species within each of these nodes. We maintained simplicity in these models by minimizing the number of variables in an effort to aid interpretation and reduce uncertainty (Reum et al. 2015), but maintained sufficient realism to capture pivotal ecological dynamics.

The research team then conducted two participatory workshops in Sitka with local residents in April 2018, one focusing on ecological components and the other on human dimensions of local fisheries. Participatory methods are particularly helpful when group interactions produce insights that may be less accessible without group dynamics (Morgan 1997, Wilkinson 1998, Kidd and Parshall 2000) and have been utilized in other contexts to elicit information about the links between human wellbeing and utilization of natural resources (McLain et al. 2013, Poe et al. 2016). With the assistance of collaborative partners in the community (including the local university, science center, and nongovernmental organizations) as well as publicly available information on testimonies to fisheries managers and the local government, newspaper articles, and web sites, we identified key informants for these workshops who have in-depth and specialized knowledge of the community's interaction with their local fisheries (Tremblay 1957, Krueger and Casey 2000). Workshop participants were contacted by phone and via e-mail by a researcher to describe the study, the intent of the research, why their specific input was being sought, e.g., expertise in the halibut longline fishery, and to invite participation. Participation in the workshops as well as voice recordings were voluntary and based on principles of informed consent (Homan 1991).

We targeted key informants from several different groups including subsistence and commercial use harvesters, harvester representatives, and fishery managers for each of the study focal 
species, community health and well-being educators and leaders, Alaska Natives and Sitka Tribe representatives, and scientists with expertise in the surrounding ecosystem structure. Workshop participants consisted of two to three representatives from most of the target groups, with a total of $n=13$ participant for the ecological workshop and $n=12$ participants for the human dimensions workshop, with several individuals participating in both. Participants represented nearly all of the major stakeholder groups and community experts in fisheries utilization in Sitka; although Sitka Tribe members were not present at the workshops, two natural resource managers for the tribe were present. Despite targeted efforts by researchers to elicit participation from the charter sector, which is an important fisheries user group in Sitka, members of this sector were not available to participate in this research. The key distinction between participants at the human dimensions and ecological workshops is that the former included community health and well-being educators and leaders, and the latter included scientists with local ecosystem expertise. The other target groups were represented at both workshops although not necessarily by the same individuals, though continuity was helpful for context. This sample size has been shown to be sufficient in purposive sampling design (Guest et al. 2006, Rohrbach et al. 2016), especially when coupled with reaching the point of theoretical data saturation (Strauss and Corbin 1990) which we detail below. The workshops lasted three hours each. Researchers used process agendas and interview guides to conduct the workshops (Krueger and Casey 2000).

The ecosystem workshop discussion centered on the identification of connections between focal species and various components of the Southeast Alaska ecosystem based on personal experiences, knowledge, and in situ observations by Sitka residents. Workshop participants were presented with a focal species and asked to identify the key environmental and biotic components that influence changes in the abundance of that particular species over time. Abundance, i.e., total number of individuals and the way these numbers vary with time, was chosen as the main population metric mainly because of its interpretability among different stakeholder groups but also because it is a reasonable predictor of extinction risk, reflects general processes that are important to all populations, and it is a measurable parameter (McElhany et al. 2000). The workshop session was divided in two sections, one for each focal species, and progressed in two phases. First, participants were provided with writing materials in the form of handouts and encouraged to draw or otherwise describe their own conceptual model for the focal species. Following the individualized exercise, participants constructed ecosystem models as a group. Ecosystem networks were drawn on whiteboards at the head of the room, with participants instructing the workshop leaders on what components to include, and where and in what direction to draw cause and effect connections. When an environmental or biotic component was identified as important by one or more participant, the workshop leaders then asked participants to identify both the direction of its effect on the focal species, or another ecosystem component, and provide a mechanistic description of the relationship.

The human dimensions workshop examined how residents of Sitka interact with their local fisheries and how those interactions may affect community well-being. The intent of this workshop was to develop a framework to identify linkages between the focal species and social, economic, and ecological well-being in Sitka (as defined by people in the community). As recommended in the literature, we developed an interview guide that consisted of nondirective questioning with open-ended topic areas to elicit spontaneous and multilayered responses (Kidd and Parshall 2000), a methodology that has been successfully utilized in similar contexts to elicit information about values associated with ecosystem usage (Gould et al. 2015, Poe et al. 2016). The interview guide for this workshop was developed around four focal discussion topic areas that were theorized to underpin these linkages: (1) the importance of these fisheries to Sitka residents, (2) factors affecting resident participation in these fisheries, (3) responses to changing fishery and environmental conditions, and (4) impacts of changing conditions on resident's capacity to derive well-being from fishery resources. These discussion topics were intended to build the well-being blocks and drivers of fisheries use, as well as the direction of the linkages between them to generate the human dimensions components of the conceptual models.

Several data and information gathering techniques were utilized throughout the workshops including handouts for participants to respond to specific topics and write general notes, major themes summarized on flip charts for immediate participant feedback (only for the human dimensions workshop), note taking by two researchers, and voice recording for later transcription (Krueger and Casey 2000). The handouts provide participants with an additional mechanism of providing feedback that is less subject to group dynamics and issues with group censoring and conformity that may arise as a result (Kidd and Parshall 2000, Carey 2016). The major themes summarized on the flip charts also served to keep track of data saturation points on each topic, and to reduce repetition. The workshops were followed by an immediate debriefing process wherein the researchers discussed the major themes that emerged during the group discussion and the context of the discussion (Kidd and Parshall 2000).

The major themes and related discussion during the ecosystem and human dimension workshops were separately summarized by the researchers and provided to participants for feedback within two weeks of the workshops itself. This follow up process served as an opportunity for participants to challenge any interpretations by the researchers and to provide further thoughts or explanations. The environmental and biological components provided during the individual and group activities were listed and coreferenced with the components already identified during the literature review process. The well-being components were added to this final list of model constituents. The connection between the ecosystem and human dimension components was specified through a "fishing" factor that represents the local fishery for the two focal species. This fishing factor had a positive link direction toward Sitka community well-being and negative direction toward the abundance of focal species.

\section{RESULTS AND DISCUSSION}

The halibut and herring coproduced conceptual models represented a comprehensive effort to understand the ecosystem structure and human aspects of the Sitka community with respect to the focal fisheries. The integrity and relevance of these models to managers and stakeholders relies on the coproduction of knowledge between scientists and the community as well as the 
integration of human well-being and ecological components of the ecosystem.

Both models were similar with respect to ecological structure and human dimensions (Fig. 3a,b). The ecological and human dimensions components, as well as the direction of linkages among these components, remained the same between the halibut and herring models. There were a total of nine environmental nodes (rectangles), 20 biota nodes (triangles), and two human dimension nodes (diamonds), one representing the fishery and the other representing 25 Sitka community well-being components (Fig. 4). Lines between model nodes indicate either a positive (arrow head) or negative (dot head) effect on the terminal group (Fig. 3a,b).

\section{Ecological model components}

About $88 \%$ of ecological model components and link directions determined during the scientific literature review process were also identified by Sitka workshop participants. This high concurrence elucidates the expertise that participants possess about the surrounding ecosystem. The unaccounted components were related to a few prey and predator species for both the halibut and herring models. For example, pollock (Gadus chalcogrammus) as prey for halibut and as predator of herring, was not identified by Sitka workshop participants. This might be explained by the spatial scale of local stakeholder observations versus published food web models (e.g., Aydin et al. 2007, Gaichas et al. 2010). The latter are conducted using groundfish diet composition summarized at the scale of the whole Gulf of Alaska and not by subareas that would be more commensurate to spatial scales appropriate to local observations. For instance, pollock are more abundant and support trawl fisheries in the central and western Gulf of Alaska and have a greater impact on regional food webs compared to eastern Gulf of Alaska where they are less abundant (Brodeur and Wilson 1996) and trawling is prohibited. The integration of LEK into available diet composition studies might thus be used as an indirect survey method for inferring differences between regional and local fish diets and abundance, when data at smaller geographic scales are not available.

The ecological model components that were solely identified by Sitka workshop participants (and not previously identified during the literature review process), were grouped into six topic groups (Tables 1a, 1b): (1) anthropogenic impacts on ecosystems, (2) fish movement and migration, (3) biological interactions, (4) local environmental factors, (5) habitat (only for herring), and (6) miscellaneous. All of these components were direct LEK contributions from the Sitka community to the research process and are discussed at length in the following paragraphs. However only some of these components were included in the final models (yellow highlighted components; Fig. 3a,b), based on the following selection criteria: (1) only components with a direct effect on the abundance of focal species, their prey, or predators, were considered, i.e., first and second order interactions, and (2) only components that have a potentially quantifiable effect on the abundance of the focal species were considered.

The motivation for the aforementioned criteria was model simplicity mainly to keep models tractable. This simplicity also offers model interpretability across stakeholders from any background, which facilitates the use of these models as a research tool. Nevertheless, trade-offs of model simplicity have to be considered (Reum et al. 2015, Harvey et al. 2016). For example, (1) aggregating several species in one node reduces functional diversity, (2) decreasing the number of links between nodes by focusing only on direct effects on the abundance of focal species oversimplifies ecosystem dynamics, (3) assuming linear dynamics between model components minimizes ecosystem complexity, and (4) constraining fishing dynamics only to the abundance of the focal species limits the research scope. Furthermore, it is important to recognize essential flaws in conceptual modeling such as potential information deficit, excess, or redundancy (Carvalho and Almeida 2018). However, the adaptability and flexibility of conceptual models due to their intuitive and visual nature should allow researchers to address some of these tradeoffs according to subsequent research objectives. Also, these models are expected to be used as a communication tool. For example, the halibut and herring models have been further illustrated to engage a broader audience and these images are expected to be used for teaching, outreaching, and touristic purposes (Appendix 3).

From the LEK generated topic groups, anthropogenic impacts on the ecosystem were identified as having an overall negative directional effect on the abundance of the focal species. Among these components, issues like bycatch, alteration of coastal habitats for human use, i.e., construction, ocean pollution, and ocean acidification were each mentioned by more than one person during the workshop, highlighting the importance of human activities as drivers of ecosystem change.

For the halibut movement and migration topic group, workshop participants made a distinction between what they called "settlers" and "travelers" in reference to short versus extensive fish migrations. This local observation might be based on fish movements between summer feeding grounds to winter spawning areas (Skud 1977, Parker 1988). Additionally, some of the juvenile and adult halibut do not return to the same feeding grounds and make extensive transboundary emigrations (Loher and Seitz 2006, Loher 2008). Workshop participants maintain that they can recognize this "movement trait" based on different physiological characteristics of fish, e.g., color, size, behavior. In the case of herring, lunar cycles were identified as a pivotal factor affecting vertical and horizontal migrations, as well as feeding behavior. This local observation is supported by a wide array of studies. For example, an increase in spawning frequency of herring has been observed during periods of full and new moons (Hay 1990). Vertical migration is also highly dependent on light intensity with fish moving to the surface at dusk and to deeper waters at dawn (Blaxter and Parrish 1965), but with a bright moonlight being sufficient to cause migration from the surface to deeper layers at nighttime (Stevenson 1962). Marine mammals were not only identified by workshop participants as herring predators, but also as a source of change in horizontal distribution. Herring schools can take strong and diverse evasive actions, e.g., schools shapechanging and dive events, in the presence of predators such humpback (Megaptera novaeangliae) and killer whales (Orcinus orca; Sharpe and Dill 1997, Nøttestad and Axelsen 1999).

Almost all of the prey-predator interactions identified by workshop participants were included in the final models as they were cross-referenced with diverse diet composition studies, with a few exceptions. Although a voracious predator, lingcod 
Fig. 3. Halibut, Hippoglossus stenolepis (a) and herring, Clupea pallasii (b) social-ecological conceptual models.

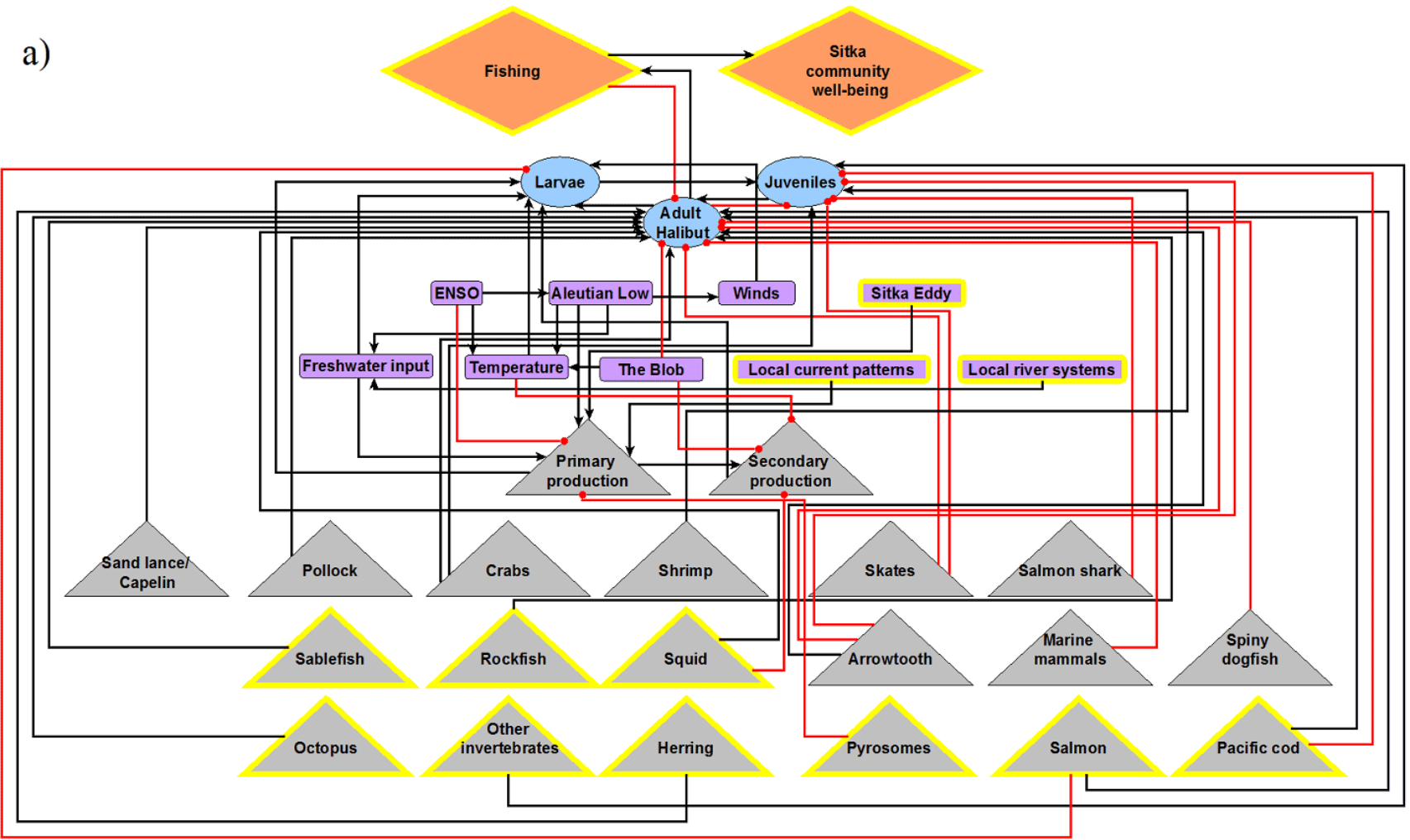

b)

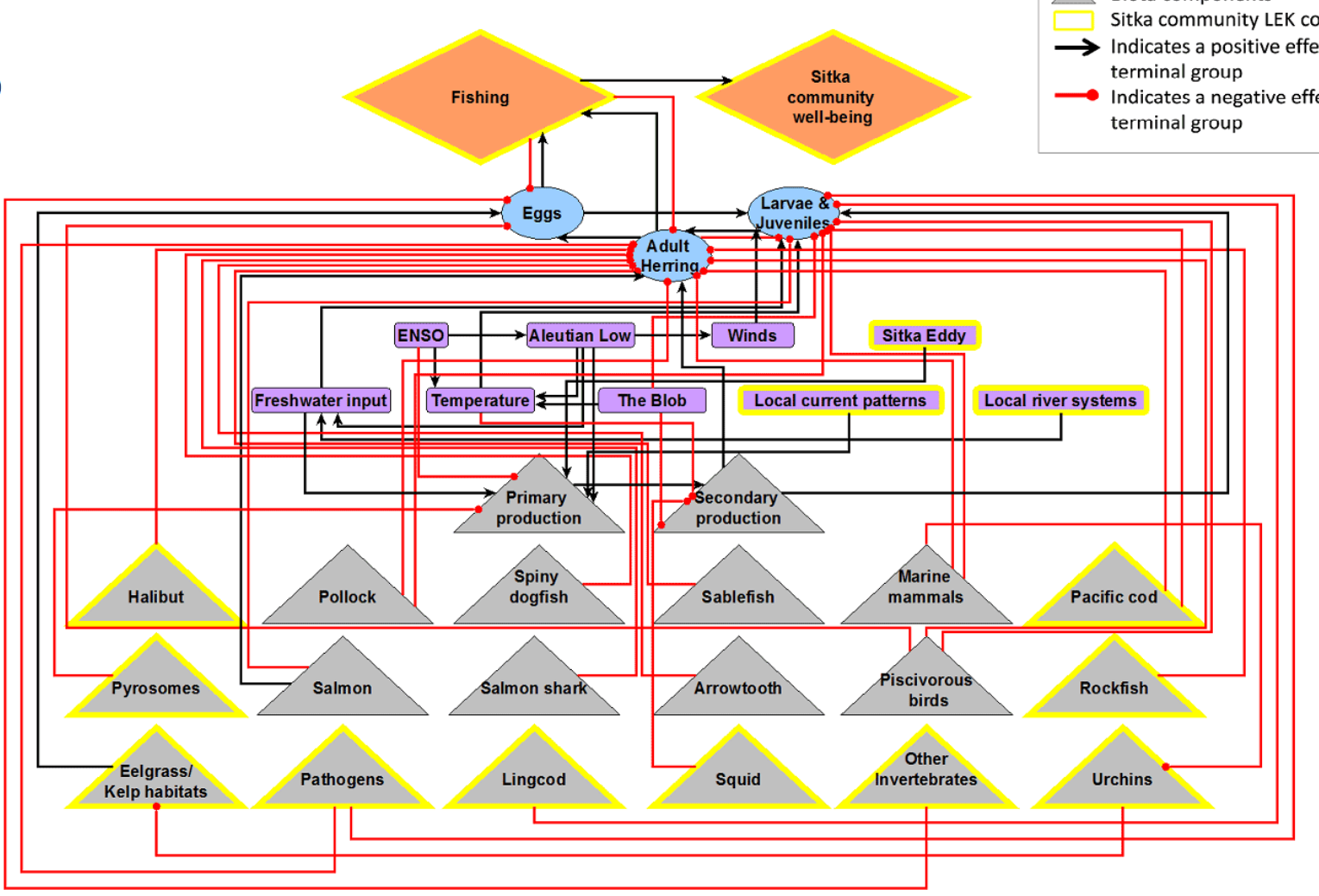


Table 1. Topic groups and model components provided by Sitka stakeholders for halibut, Hippoglossus stenolepis (a) and herring, Clupea pallasii (b) species.

\begin{tabular}{|c|c|c|c|c|c|}
\hline $\begin{array}{l}\text { Anthropogenic } \\
\text { impacts on ecosystem }\end{array}$ & $\begin{array}{l}\text { Fish movement and } \\
\text { migration }\end{array}$ & Biological interactions & $\begin{array}{l}\text { Local environmental } \\
\text { factors }\end{array}$ & Habitat & Miscellaneous \\
\hline \multicolumn{6}{|r|}{ 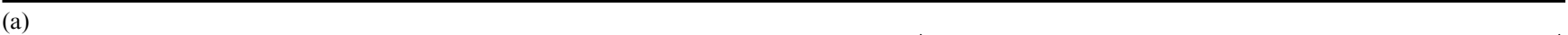 } \\
\hline Pollution & Settlers vs. Travelers & $\begin{array}{l}\text { Predators } \\
\text { Pacific cod } \\
\text { Salmon }^{\dagger} \\
\text { Lingcod } \\
\text { Other fish }\end{array}$ & Sitka gyre ${ }^{\dagger}$ & & Pyrosome bloom $(2017)^{\dagger}$ \\
\hline Microplastics & & $\begin{array}{l}\text { Prey } \\
\text { Rockfish }^{\dagger} \\
\text { Squid }^{\dagger} \\
\text { Salmon }^{\dagger} \\
\text { Octopus }^{\dagger} \\
\text { Herring }^{\dagger} \\
\text { Sablefish }^{\dagger} \\
\text { Sea snails (Oregon hairy }_{\text {triton) and other }} \\
\text { invertebrates } \\
\text { Other fish }\end{array}$ & $\begin{array}{l}\text { Short steep river } \\
\text { systems }^{\dagger}\end{array}$ & & $\begin{array}{l}\text { King salmon collapse } \\
\text { (induces more fishing } \\
\text { pressure on halibut) }\end{array}$ \\
\hline $\begin{array}{l}\text { Fishing gears } \\
\text { Bycatch/PSC } \\
\text { Ocean acidification }\end{array}$ & & & Local current patterns $^{\dagger}$ & & \\
\hline \multicolumn{6}{|l|}{ (b) } \\
\hline Pollution & $\begin{array}{l}\text { Moonlight/moon cycles } \\
\text { (vertical and horizontal } \\
\text { migration, feeding behavior) }\end{array}$ & $\begin{array}{l}\text { Predators } \\
\text { Halibut }^{\dagger} \\
\text { Crustaceans and other }^{\dagger} \text { invertebrates }^{\dagger} \\
\text { Rockfish }^{\dagger} \\
\text { Pacific cod } \\
\text { Lingcod }^{\dagger} \\
\text { Dolly Varden } \\
\text { Other fish }\end{array}$ & Sitka gyre ${ }^{\dagger}$ & Eelgrass health $^{\dagger}$ & Pyrosome bloom $(2017)^{\dagger}$ \\
\hline Microplastics & $\begin{array}{l}\text { Marine mammals (whales } \\
\text { and sea lions dictating } \\
\text { vertical and horizontal } \\
\text { distribution) }\end{array}$ & $\begin{array}{l}\text { Competitors } \\
\text { Squid }^{\dagger}\end{array}$ & $\begin{array}{l}\text { Short steep river } \\
\text { systems }\end{array}$ & Kelp abundance $^{\dagger}$ & Diseases $^{\dagger}$ \\
\hline Fishing gears & & & Local current patterns ${ }^{\dagger}$ & $\begin{array}{l}\text { Sea otter - Sea } \\
\text { urchins - Kelp trophic } \\
\text { interaction }\end{array}$ & $\begin{array}{l}\text { Capelin and sand lance } \\
\text { abundance (as } \\
\text { alternative food source } \\
\text { for predators) }\end{array}$ \\
\hline $\begin{array}{l}\text { Construction } \\
\text { Logging } \\
\text { Ocean acidification }\end{array}$ & & & & & \\
\hline
\end{tabular}

(Ophiodon elongatus) was not included as a halibut predator because this generalist predator has no reported preference for halibut (Shaw and Hassler 1989, ADFG 2017). Similarly, Dolly Varden char (Salvelinus malma) was not included as a significant predator of herring because herring are not among its preferred prey (Rooper and Haldorson 2000, Bishop and Green 2001). Neither lingcod nor Dolly Varden were highlighted by workshop participants as primary sources of halibut or herring mortality.

As expected, local environmental factors were mentioned by the majority of participants during the workshop. Southeast Alaska has spatial heterogeneity in physical processes that control local circulation and mixing, which create prolific and diverse marine habitats (Weingartner et al. 2009). The Sitka eddy (a welldeveloped, anticyclonic baroclinic eddy, located a few hundred kilometers off Sitka), massive freshwater input, and local current patterns were all identified as critical physical processes driving recruitment or survival of the focal species in Sitka Sound. Macronutrients from the basin are provided to the coastal system through a number of processes including topographic steering, eddies, upwelling in response to horizontal shear in the barrier jets, and on-shelf flux in the Ekman layer (Stabeno et al. 2004). Large quantities of freshwater discharge promote stratification in the upper fjord, while strong tidal currents enhance vertical mixing (Stabeno et al. 2004). Intermediate stratification, higher light levels, and nutrient renewal are all conditions that promote high primary productivity in this area (Whitney et al. 2005, Crawford et al. 2007, Ladd 2007).

The "Habitat" topic group was only identified by workshop participants for herring because spawning occurs on both eelgrass and kelp forests. Therefore, factors affecting the structure of these 
Fig. 4. Sitka halibut (Hippoglossus stenolepis) and herring (Clupea pallasii) abundance-based well-being components. Signs (+ positive; - negative; \pm positive or negative) indicate relationship type between each component and abundance of focal species. This Venn diagram represents the expanded version of the "community well-being" diamond in Fig. 3a,b.

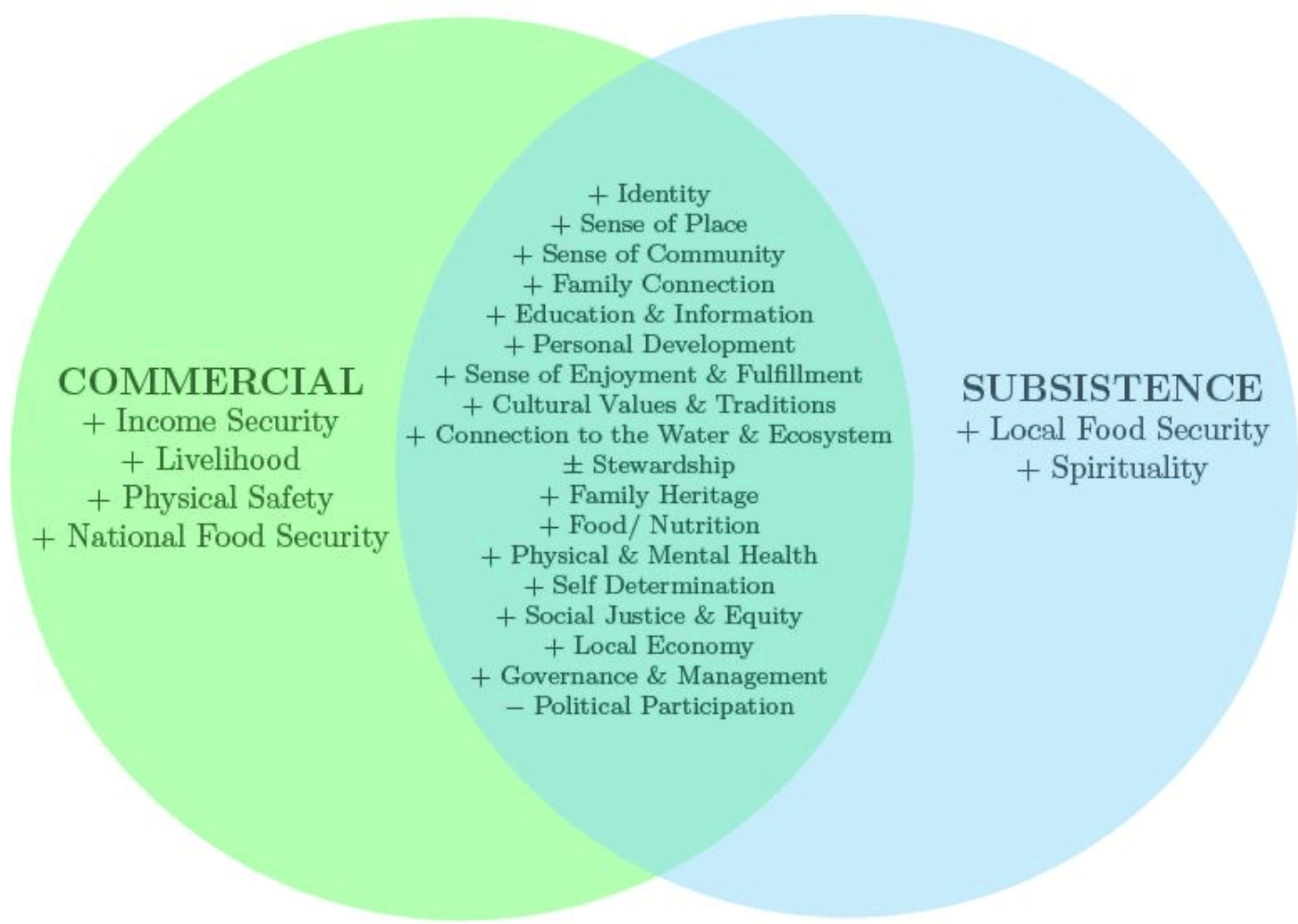

habitats were discussed. For example, the interaction between sea otters, sea urchins, and kelp was identified as a potential ecological process that might affect herring abundance. The maintenance of diverse spawning locations in Southeast Alaska was a critical issue raised by Sitka workshop participants. Marine vegetation is known to benefit herring eggs by decreasing the risk of benthic predation (Carls et al. 2008, Moss et al. 2016, Keeling et al. 2017).

Some other concepts mentioned during the workshop were grouped under a "Miscellaneous" topic group. A pyrosome bloom, which occurred in the Northeast Pacific in 2017, was identified as an important factor for both the halibut and herring models. Pyrosomes are free-floating colonial tunicates with high filtration rates that can potentially reduce phytoplankton biomass locally (Archer et al. 2018, Brodeur et al. 2018). However, it remains unclear how extensive this grazing pressure may have been in 2017 and what were the real implications of this bloom for coastal productivity in this area (Archer et al. 2018, Brodeur et al. 2018). Pathogens, specifically viruses, were identified by workshop participants for herring. Viral hemorrhagic septicemia (VHS) and the associated virus (VHSV) have been isolated from herring since the 1990s and have been associated with reduction in fitness and mortality of juvenile fish (Meyers et al. 1999, Kocan et al. 2001, Marty et al. 2003). Finally, other species interactions were mentioned as potential sources of change in the abundance of focal species. In the case of halibut, participants alluded to a potential increase of fishing pressure on halibut whenever
Chinook salmon (Oncorhynchus tshawytscha) abundance was low. In the case of herring, participants assumed that an increase in abundance of other forage fish, such as capelin (Mallotus villosus) and Pacific sand lance (Ammodytes hexapterus), would reduce natural mortality of herring by reducing predation pressure.

\section{Human dimensions model components}

Sitka workshop participants discussed the linkages between specific components of well-being and subsistence and commercial fisheries use (Fig. 4). They identified a core set of well-being components many of which have been identified previously in research efforts on marine ecosystem use and human well-being, reflecting conceptual validity (Gould et al. 2015, Breslow et al. 2016, Poe et al. 2016, Biedenweg 2017). In extensions of the human dimensions research in the community (Szymkowiak and Kasperski, unpublished manuscript), study participants moved some components to reflect that they are relevant for both commercial and subsistence users (social justice and equity and self-determination) and slightly expanded upon the original list by bifurcating food security into local and national components and adding governance and management. Because no additional components were noted at the end of these multiple efforts in the community and these components reflect ones previously identified with extensive efforts by a team of social scientists (Breslow et al. 2016), we determined data saturation (Strauss and Corbin 1990, Guest et al. 2006). However, the 
Table 2. Human well-being components, their definitions, and example phrases used by Sitka focus group participants in discussion about importance of participating in the halibut (Hippoglossus stenolepis) and herring (Clupea pallasii) fisheries.

\begin{tabular}{|c|c|c|}
\hline Human well-being component & Definition & Example phrases used by participants \\
\hline Identity & Sense of self and community identity & $\begin{array}{l}\text { "Fishing is a way of life," "Sitka is a fishing community," } \\
\text { "pride" }\end{array}$ \\
\hline Sense of place & Meaning and identity connected to a place & "We love this place. We love this way of life" \\
\hline Sense of community & Social relationships within community & "Respect among people in community" "sharing networks" \\
\hline Family connection & Intra-family relationships and bonding & "Quality time for family" \\
\hline Education and Information & $\begin{array}{l}\text { Possession and transmission of knowledge, } \\
\text { information, and skills }\end{array}$ & "The ocean is a classroom" \\
\hline Personal development & Building human capital & "Learning new skills" \\
\hline $\begin{array}{l}\text { Sense of enjoyment and } \\
\text { fulfillment }\end{array}$ & Experience of pleasure and achievement of goals & "Outdoor enjoyment" \\
\hline Cultural values and traditions & Transfer of customs, practices, values between people & $\begin{array}{l}\text { "Harvests are on their schedule - the seasonality of the fish } \\
\text { themselves" }\end{array}$ \\
\hline $\begin{array}{l}\text { Connection to the water and } \\
\text { ecosystem }\end{array}$ & Physical and psychological association with water & "Connection to nature/outdoors" \\
\hline Stewardship & Sustainable practices and conservation efforts & $\begin{array}{l}\text { "Necessity and desire of passing along the resource to the } \\
\text { next generation" }\end{array}$ \\
\hline Family heritage & Generational connections to uses & "Passing on traditions and work ethic to kids" \\
\hline Food/Nutrition & $\begin{array}{l}\text { Food that meets dietary needs and personal } \\
\text { preferences }\end{array}$ & "Local fish provide important high quality food" \\
\hline Mental health & $\begin{array}{l}\text { Perception of quality of life and emotional well- } \\
\text { being }\end{array}$ & "Emotional and psychological value of being on the ocean" \\
\hline Physical health & Well-being of the body & "Have that food and have that level of health" \\
\hline Political participation & Voice in advocacy and political process & "Participating in Board of Fish meetings" \\
\hline Local food security & Ensured access to safe and nutritious food, locally & "Don't depend on barge," "fisheries are our road system" \\
\hline National food security & $\begin{array}{l}\text { Ensured access to safe and nutritious food, } \\
\text { nationally }\end{array}$ & "Food security at the national level" \\
\hline Spirituality & Sacredness, deep meaning, and values & "Sacredness," "customary and traditional way of life" \\
\hline Self determination & Independence and agency & "Freedom and independence" \\
\hline Social justice & Equitable distribution of resources & $\begin{array}{l}\text { "Equity issues," "access," “can’t afford fish with food } \\
\text { stamps" }\end{array}$ \\
\hline Income security & $\begin{array}{l}\text { Evidence of stability and ability to plan into the } \\
\text { future }\end{array}$ & "Reliance on income, seasonal fishing jobs" \\
\hline Livelihood & Employment and income & "Employment," "income pathways" \\
\hline Local economy & Production of goods and services & $\begin{array}{l}\text { "Support services," "harbor infrastructure," "multiplier } \\
\text { effects" }\end{array}$ \\
\hline Governance and Management & $\begin{array}{l}\text { Effective and efficient government that is readily } \\
\text { accessible to the public }\end{array}$ & "Public access to science," "dissemination of information" \\
\hline Physical safety & Protection from exposure to threats & "Avoiding poor weather conditions" \\
\hline
\end{tabular}

representativeness of our findings is limited to the user groups that participated in the study, which unfortunately excluded Sitka Tribe members and the charter fishing sector.

The well-being components presented in Figure 4 were adapted from Breslow et al. (2016) for human well-being categories associated with uses of the California Current LME. The components were determined on the basis of the congruence of the phrases used by workshop participants to describe the importance and value of fisheries use and the attribute definitions used in Breslow et al. (2016). For example, participants noted that "Sitka is a fishing community" and that "fishing is a way of life," which were classified as sense of place and community identity and summarized as "identity" for a well-being component. Definitions of each well-being component along with example phrases used by participants that were classified under each component are provided in Table 2 . These definitions vary slightly from those utilized in Breslow et al. (2016) to capture unique distinctions identified by participants and achieve local validity. For instance, there was considerable discussion about the connection of fisheries to a personal and community identity, sense of place, and sense of community, which were differentiated by participants on the basis of emotional ties, geography, and social relationships.

For most of the well-being components, the group discussion conveyed a positive relationship, i.e., sign, with fisheries abundance. However, participants discussed competition over diminished fisheries as a driver of political participation (a component of well-being previously identified by Breslow et al. 2016), incentivizing their engagement in fisheries management meetings to advocate for their user group and point of view, implying a negative relationship. Workshop participants noted that the relationship between abundance and stewardship was also differentiated by species life stage and use type. Users may purposely avoid harvesting fish during their juvenile stage in an effort to provide for greater yields in the long-run. Participants noted that flexibility in switching species for stewardship purposes may be differentially constrained between commercial and subsistence users based on inter alia their access to alternative 
fishing permits, gear, vessels, opportunity costs, and the interchangeability of the species themselves. For example, natural resource managers for Sitka Tribe noted that because there is no substitute for the cultural and spiritual importance of herring eggs to the Alaska Natives of Sitka, their participation in this subsistence fishery is largely irrespective of costs. Therefore, recent changes in the location, timing, and abundance of herring spawn around Sitka (ADFG 2018) have increased their costs of participating in this subsistence fishery, but not their obligation to do so.

As described before, Figure 4 does not differentiate between halibut and herring because these well-being components were consistently identified for both fisheries. However, participants noted that these species are not interchangeable in terms of how they are processed, eaten, and the cultural values and traditions associated with their acquisition and consumption. Furthermore, we did not seek to weigh these components in any way although the degree of the importance of any one component could be differentiated for herring and halibut, relative to other components for each fishery or between fisheries. For example, herring eggs were noted by participants as being particularly important for their spiritual and cultural values to Alaska Native residents of Sitka, while halibut may be more important, for example, with respect to food security because of the volume of subsistence harvests in this fishery.

Most of the well-being components identified by Sitka workshop participants were concordant with each other for both subsistence and commercial fishing users, as seen in Figure 4. Nevertheless, participation in the commercial sector was linked with well-being components for employment, income, and economy that were not relevant for subsistence users. Physical safety was identified by commercial participants in relation to fisheries abundance in that the fleet could avoid poor weather conditions when healthy stocks coupled with management paradigms provide for long fishing seasons. Subsistence users, on the other hand, note that they are unlikely to participate in fisheries in bad weather. Subsistence users also identified several well-being components that were unique to this use type. Discussion about food security, selfdetermination, and social justice overlapped to some extent on themes of equity, access, agency, and security. Participants discussed how subsistence fishing provided for equitable access to resources for economically vulnerable populations that may be unaffordable at local grocery stores, a sense of security in being self-sufficient, and the expectation that the food was not contaminated. One participant likened local fisheries to a road system in other parts of the country, providing goods and services and connecting communities in Southeast Alaska, which are largely isolated and accessible only by water and air transportation. Participants' spiritual connection to fisheries was also noted specifically with respect to subsistence uses.

Participants noted that commercial and subsistence fishing are integral to personal and community identity in Sitka and are a source of pride. Fishing permeates various aspects of the community from its physical layout and aesthetic beauty, with its many harbors and working waterfronts, to the types of employment and education opportunities that it provides. For example, participants discussed the importance of fishing to employment opportunities not just directly in commercial fisheries, but support service businesses (processing, cold storage, etc.), and natural resource management, as well. Local fisheries, and the ocean ecosystem more broadly, also provide educational opportunities for residents from primary through graduate school with hands-on learning opportunities, as well as an important source of income for local youth to earn money to pay for college. The opportunities afforded by these fisheries also help the community to retain its youth, which was highlighted as critical to its longevity and capacity to sustain healthy food sharing networks, for example, which values the provision of resources to village elders.

Across both commercial and subsistence users, participants discussed the value of fisheries participation to physical and mental health, building personal connections and social relationships, and maintaining cultural values and traditions. There was extensive discussion about the reliance on local fisheries for sustenance, nutrition, and overall physical health benefits. Participants also noted the contribution of fisheries participation to emotional wellness, sustaining a connection to the water and the outdoors more generally, and providing an enjoyable and fulfilling activity that builds skill sets. Cultural and family wellbeing were also deeply rooted in fisheries participation for workshop participants with various associated aspects including spending quality time together, passing on harvesting and processing knowledge and traditions, and retaining a commercial fishing family heritage through multiple generations.

Some well-being components were discussed specifically in response to the interview guide question about the impacts of changing conditions on resident capacity to derive well-being. Participants noted that increasing competition over decreasing resources has negatively affected livelihoods for the local commercial fishing fleet, their sense of community, enjoyment and fulfillment, mental health, capacity to sustain cultural values and traditions, and the spirituality of participating in certain fisheries. Interestingly, for both commercial and subsistence use participants, increasing operating costs in response to decreasing fish abundance and associated restrictive management changes have led to increasing reliance on information and cost-sharing networks in the community, which may in turn actually increase social bonds in the community.

\section{CONCLUSION}

The implementation of EBM presents itself with numerous challenges to decision makers. Many of these challenges are related to the elucidation of the interconnectedness of the dynamic physical environment and the coupled social-ecological system (Fletcher et al. 2014). IEAs are a tool designed to minimize those challenges (Fletcher et al. 2014). One of the early stages of IEA development is the construction of conceptual models as an illustrative method to identify, integrate, and communicate relevant components and linkages in marine ecosystems. We presented conceptual models for Pacific halibut and Pacific herring as the basis of an IEA approach for Southeast Alaska. These models were a coproduct of Sitka stakeholders and scientists. Assembling interdisciplinary information from diverse sources and documenting available scientific literature resulted in the cocreation of a visual representation of focal fisheries in the Sitka Sound ecosystem. These conceptual models are useful communication tools for stakeholders and scientists alike to provide a holistic understanding of the ecosystem structure. Importantly, these conceptual models have the potential to (1) 
identify knowledge gaps in the biology, food web interactions, and important economic and social outcomes of focal species, (2) inform ecosystem research needs and provide the basis for developing and testing causal hypotheses, and (3) be used in modeling techniques to simulate diverse management scenarios.

Our models were derived from a participatory process that serves to capture and integrate LEK, and thus local management needs, into the IEA framework which is essential to build local community trust in management programs (Ingram et al. 2018). The amalgamation of LEK and scientific knowledge cannot be overstated. The transferable knowledge between scientists and stakeholders inherently improves the accuracy in describing complex social-ecological systems. Furthermore, there is literature indicating that the linkages between well-being and natural resource use may be context specific depending on the scale of the categorization, from indicator to component (Biedenweg 2017), so that well-being components linked to resource use should be localized to the extent possible. For this study, LEK also provided local and long-term perspectives on the distribution and abundance of our focal species. By crossreferencing LEK with conventional scientific sources, such as peer review publications, we also improved our overall capacity of interpreting local biological and ecological dynamics. Using participatory methods to construct conceptual models also helps to develop a social learning between stakeholders and scientists and enhances transparency of the assumptions built into the models (Salter et al. 2010). Decision making and management also require incorporation of stakeholder input for successful implementation. Stakeholder engagement is a required component of EBM as specified by the Magnuson-Stevens Fishery Conservation and Management Act (Wadsworth et al. 2014, Glass et al. 2015).

Conceptual models can evolve from being an illustrative and communicative tool of the ecosystem structure to a simulation modeling tool (Harvey et al. 2016). For example, qualitative network models (QNMs) are mathematical representations in which perturbations are assessed for their qualitative impact on the system of interest (Reum et al. 2015). They are used to operationalize conceptual models (Harvey et al. 2016), allowing to (1) explore various management actions, as well as ecological, economic, or social shocks, (2) evaluate trade-offs among these scenarios, and (3) determine any unexpected outcomes from proposed management strategies (Reum et al. 2015). In future research, we intend to develop QNMs based on the conceptual models presented here. By conducting a series of simulations we will try to understand how different components of the model respond to a particular perturbation or environmental condition and we will evaluate trade-offs across human well-being components. It is paramount that any potential identification of sustainable management strategies resulting from these modeling techniques will be based on conceptual models derived from a participatory process and transdisciplinary knowledge integration.

We are also working on expanding the human dimensions linkages of our conceptual model. A pivotal part of this paper was the linkage between the abundance of the focal species and human well-being components for Sitka residents. However, workshop participants discussed a variety of other factors that affect their decisions about fisheries participation and whether and how they derive well-being from their local fisheries. Researchers are currently synthesizing this information, which coupled with outputs from a follow-up workshop in Sitka, will be utilized to develop quantitative indicators of the multiple facets of fisheries participation and human well-being for Sitka residents beyond abundance-based linkages.

We define our research process here as "placed-based participatory IEA" because it includes the development of an IEA framework, at a local scale, with active and direct participation of community members. The next step of the IEA loop framework will include the operationalization of local EBM objectives and the development of local social and ecological quantitative indicators with input from Sitka community residents. The local ecosystem conceptualization presented here, provides the stepping-stone of the entire IEA framework, which is expected to be replicated in other Gulf of Alaska communities, contingent on funding. Therefore, the long-term goal of the Gulf of Alaska IEA program is to incorporate social-ecological distinctive regions of the Gulf of Alaska LME into one unifying framework. This process will likely result in the composition of a more holistic and integrated approach to manage sustainable Alaskan fisheries and communities.

Responses to this article can be read online at: http://www.ecologyandsociety.org/issues/responses. php/11074

\begin{abstract}
Acknowledgments:
We thank Dr. Kerim Aydin for the guidance provided during weekly meetings where the Gulf of Alaska IEA overall plan was developed. We also thank Sarah Wise, Melissa Rhodes-Reese, Laura Nelson, and Cheryl Barnes for the help provided during the development of this study, including nurturing comments and suggestions. The Sitka ecological connections focus group planning and logistics benefited immensely from discussion with Drs. Stephanie Zador, Sean McDonald, Jonathan Reum, and Kirstin Holsman. We also thank the Alaska Fisheries Science Center Communications team; Rebecca White, Marjorie Mooney-Seus, and Paul Irvin, for the incredible work they did in illustrating these models for a much broader audience. We greatly appreciate the Sitka community participation in our focus groups without whom this research would not be possible. We especially want to thank Rebecca Shuford, program manager for NOAA's national IEA program, and the Sitka Sound Science center for hosting our focus groups. This publication is the result of research sponsored by the Cooperative Institute for Alaska Research with funds from the National Oceanic and Atmospheric Administration's Integrated Ecosystem Assessment Program under cooperative agreement NA13OAR4320056 with the University of Alaska.
\end{abstract}

\section{LITERATURE CITED}

Alaska Department of Fish and Game (ADFG). 2017. Lingcod (Ophiodon elongatus) Species profile. ADFG, Juneau, Alaska, USA. [online] URL: http://www.adfg.alaska.gov/index.cfm? adfg=lingcod.main 
Alaska Department of Fish and Game (ADFG). 2018. 1964-2017 Sitka Sound herring spawn locations. ADFG, Juneau, Alaska, USA. [online] URL: http://www.adfg.alaska.gov/index.cfm? adfg=commercialbyareasoutheast.herring_spawnlocations

Alaska Fisheries Science Center (AFSC). 2016. Community snapshots. Sitka. AFSC, Seattle, Washington, USA. [online] URL: https://www.nefsc.noaa.gov/read/socialsci/afsc/createReport. php?state $=$ AK\&community $=$ Sitka

Archer, S. K., A. S. Kahn, S. P. Leys, T. Norgard, F. Girard, C. Du Preez, and A. Dunham. 2018. Pyrosome consumption by benthic organisms during blooms in the northeast Pacific and Gulf of Mexico. Ecology 99(4):981-984. https://doi.org/10.1002/ ecy. 2097

Aydin, K., S. Gaichas, I. Ortiz, D. Kinzey, and N. Friday. 2007. A comparison of the Bering Sea, Gulf of Alaska, and Aleutian Islands large marine ecosystems through food web modeling. U.S. Department of Commerce. NOAA Technical Memorandum NMFS-AFSC-178, Seattle, Washington, USA.

Biedenweg, K. 2017. A comparative study of human well-being indicators across three Puget Sound regions. Society and Natural Resources 30(3):362-376. https://doi.org/10.1080/08941920.2016.1209606

Bishop, M. A., and S. P. Green. 2001. Predation on Pacific herring (Clupea pallasi) spawn by birds in Prince William Sound, Alaska. Fisheries Oceanography 10(s1):149-158. https://doi.org/10.1046/ j.1054-6006.2001.00038.X

Blaxter, J. H. S., and B. Parrish. 1965. The importance of light in shoaling, avoidance of nets and vertical migration by herring. ICES Journal of Marine Science 30(1):40-57. https://doi. org/10.1093/icesjms/30.1.40

Breslow, S. J., B. Sojka, R. Barnea, X. Basurto, C. Carothers, S. Charnley, S. Coulthard, N. Dolšak, J. Donatuto, C. GarcíaQuijano, et al. 2016. Conceptualizing and operationalizing human well-being for ecosystem assessment and management. Environmental Science and Policy 66:250-259. https://doi. org/10.1016/j.envsci.2016.06.023

Brodeur, R., I. Perry, J. Boldt, L. Flostrand, M. Galbraith, J. King, J. Murphy, K. Sakuma, and A. Thompson. 2018. An unusual gelatinous plankton event in the NE Pacific: the great Pyrosome bloom of 2017. PICES Press 26(1):22-27.

Brodeur, R. D., and M. T. Wilson. 1996. A review of the distribution, ecology and population dynamics of age- 0 walleye pollock in the Gulf of Alaska. Fisheries Oceanography 5:148-166. https://doi.org/10.1111/j.1365-2419.1996.tb00089.x

Carey, M. A. 2016. Focus groups - What is the same, what is new, what is next? Qualitative health research 26(6):731-733. https:// doi.org/10.1177/1049732316636848

Carls, M. G., S. Johnson, M. Lindeberg, A. Neff, P. Harris, and R. Waples. 2008. Status review of Lynn Canal herring (Clupea pallasii). Biological Review Team Report NOAA-NMFS-AFSC, Seattle, Washington, USA.

Carvalho, V. A., and J. P. A. Almeida. 2018. Toward a wellfounded theory for multi-level conceptual modeling. Software \& Systems Modeling 17(1):205-231. https://doi.org/10.1007/ s10270-016-0538-9
Crawford, W. R., P. J. Brickley, and A. C. Thomas. 2007. Mesoscale eddies dominate surface phytoplankton in northern Gulf of Alaska. Progress in Oceanography 75(2):287-303. https:// doi.org/10.1016/j.pocean.2007.08.016

Fey, M., S. Weidlich, N. Leuthold, R. Ames, and M. Downs. 2016. Fishing communities of Alaska engaged in federally managed fisheries. North Pacific Fishery Management Council, Anchorage, Alaska, USA.

Fletcher, P. J., C. R. Kelble, W. K. Nuttle, and G. A. Kiker. 2014. Using the integrated ecosystem assessment framework to build consensus and transfer information to managers. Ecological Indicators 44:11-25. https://doi.org/10.1016/j.ecolind.2014.03.024

Gaichas, S. K., K. Y. Aydin, and R. C. Francis. 2010. Using food web model results to inform stock assessment estimates of mortality and production for ecosystem-based fisheries management. Canadian Journal of Fisheries and Aquatic Sciences 67(9):1490-1506. https://doi.org/10.1139/F10-071

Glass, J. R., G. H. Kruse, and S. A. Miller. 2015. Socioeconomic considerations of the commercial weathervane scallop fishery off Alaska using SWOT analysis. Ocean and Coastal Management 105:154-165. https://doi.org/10.1016/j.ocecoaman.2015.01.005

Gould, R. K., S. C. Klain, N. M. Ardoin, T. Satterfield, U. Woodside, N. Hannahs, G. C. Daily, and K. M. Chan. 2015. A protocol for eliciting nonmaterial values through a cultural ecosystem services frame. Conservation Biology 29(2):575-586. https://doi.org/10.1111/cobi.12407

Guest, G., A. Bunce, and L. Johnson. 2006. How many interviews are enough? An experiment with data saturation and variability. Field Methods 18(1):59-82. https://doi.org/10.1177/1525822x05279903

Harvey, C. J., J. C. Reum, M. R. Poe, G. D. Williams, and S. J. Kim. 2016. Using conceptual models and qualitative network models to advance integrative assessments of marine ecosystems. Coastal Management 44(5):486-503. https://doi.org/10.1080/08920753.2016.1208881

Hay, D. E. 1990. Tidal influence on spawning time of Pacific herring (Clupea harengus pallasi). Canadian Journal of Fisheries and Aquatic Sciences 47(12):2390-2401. https://doi.org/10.1139/ f90-266

Himes-Cornell, A. H., K. R. Hoelting, C. Maguire, L. MungerLittle, J. Lee, J. Fisk, R. G. Felthoven, C. Geller, and P. Little. 2013. Community profiles for North Pacific Fisheries-Alaska. U. S. Department of Commerce. NOAA Technical Memorandum NMFS-AFSC-259, Seattle, Washington, USA.

Homan, R. 1991. The ethics of social research. Addison-Wesley Longman, London, UK.

Ingram, R. J., K. L. Oleson, and J. M. Gove. 2018. Revealing complex social-ecological interactions through participatory modeling to support ecosystem-based management in Hawai'i. Marine Policy 94:180-188. https://doi.org/10.1016/j.marpol.2018.05.002

International Council for the Exploration of the Sea (ICES). 2017. Interim Report of the ICES/PICES/PAME Working Group on Integrated Ecosystem Assessment (IEA) for the Central Arctic Ocean. WGICA Report. Steering group on Integrated Ecosystem Assessments ICESCM 2017/SSSGIEA:11, Seattle, Washington, USA. 
Keeling, B., M. Hessing-Lewis, C. Housty, D. K. Okamoto, E. J. Gregr, and A. K. Salomon. 2017. Factors driving spatial variation in egg survival of an ecologically and culturally important forage fish. Aquatic Conservation: Marine and Freshwater Ecosystems 27 (4):814-827. https://doi.org/10.1002/aqc. 2757

Kidd, P. S., and M. B. Parshall. 2000. Getting the focus and the group: enhancing analytical rigor in focus group research. Qualitative Health Research 10(3):293-308. https://doi. org/10.1177/104973200129118453

Kocan, R. M., P. K. Hershberger, N. E. Elder, and J. R. Winton. 2001. Epidemiology of viral hemorrhagic septicemia among juvenile Pacific herring and Pacific sand lances in Puget Sound, Washington. Journal of Aquatic Animal Health 13(2):77-85. https://doi.org/10.1577/1548-8667(2001)013<0077:EOVHSA>2.0. $\mathrm{CO} ; 2$

Krueger, R. A., and M. A. Casey. 2000. Focus groups: a practical guide for applied research. SAGE, Thousand Oaks, California, USA.

Ladd, C. 2007. Interannual variability of the Gulf of Alaska eddy field. Geophysical Research Letters 34(11):1-5. https://doi. org/10.1029/2007GL029478

Levin, P. S., S. J. Breslow, C. J. Harvey, K. C. Norman, M. R. Poe, G. D. Williams, and M. L. Plummer. 2016a. Conceptualization of social-ecological systems of the California current: an examination of interdisciplinary science supporting ecosystembased management. Coastal Management 44(5):397-408. https:// doi.org/10.1080/08920753.2016.1208036

Levin, P. S., M. J. Fogarty, S. A. Murawski, and D. Fluharty. 2009. Integrated ecosystem assessments: developing the scientific basis for ecosystem-based management of the ocean. PLoS Biology 7 (1):e1000014. https://doi.org/10.1371/journal.pbio.1000014

Levin, P. S., T. B. Francis, and N. G. Taylor. 2016b. Thirty-two essential questions for understanding the social-ecological system of forage fish: the case of Pacific Herring. Ecosystem Health and Sustainability 2(4):e01213. https://doi.org/10.1002/ehs2.1213

Link, J. S., and H. I. Browman. 2014. Integrating what? Levels of marine ecosystem-based assessment and management. ICES Journal of Marine Science 71(5):1170-1173. https://doi. org/10.1093/icesims/fsu026

Loher, T. 2008. Homing and summer feeding site fidelity of Pacific halibut (Hippoglossus stenolepis) in the Gulf of Alaska, established using satellite-transmitting archival tags. Fisheries Research 92(1):63-69. https://doi.org/10.1016/j.fishres.2007.12.013

Loher, T., and A. Seitz. 2006. Seasonal migration and environmental conditions of Pacific halibut Hippoglossus stenolepis, elucidated from pop-up archival transmitting (PAT) tags. Marine Ecology Progress Series 317:259-271. https://doi. org/10.3354/meps317259

Long, R. D., A. Charles, and R. L. Stephenson. 2015. Key principles of marine ecosystem-based management. Marine Policy 57:53-60. https://doi.org/10.1016/j.marpol.2015.01.013

Marasco, R. J., D. Goodman, C. B. Grimes, P. W. Lawson, A. E. Punt, and T. J. Quinn II. 2007. Ecosystem-based fisheries management: some practical suggestions. Canadian Journal of Fisheries and Aquatic Sciences 64(6):928-939. https://doi. org/10.1139/f07-062
Marty, G. D., T. J. Quinn II, G. Carpenter, T. R. Meyers, and N. H. Willits. 2003. Role of disease in abundance of a Pacific herring (Clupea pallasi) population. Canadian Journal of Fisheries and Aquatic Sciences 60(10):1258-1265. https://doi.org/10.1139/ $\underline{\text { 003-109 }}$

McElhany, P., M. H. Ruckelshaus, M. J. Ford, T. C. Wainwright, E. P. Bjorkstedt. 2000. Viable salmonid populations and the recovery of evolutionarily significant units. U.S. Department of Commerce. NOAA Technical Memorandum NMFS-AFSC-42, Seattle, Washington, USA.

McLain, R., M. Poe, K. Biedenweg, L. Cerveny, D. Besser, and D. Blahna. 2013. Making sense of human ecology mapping: an overview of approaches to integrating socio-spatial data into environmental planning. Human Ecology 41(5):651-665. https:// doi.org/10.1007/s10745-013-9573-0

Meyers, T. R., S. Short, and K. Lipson. 1999. Isolation of the North American strain of viral hemorrhagic septicemia virus (VHSV) associated with epizootic mortality in two new host species of Alaskan marine fish. Diseases of Aquatic Organisms 38 (2):81-86. https://doi.org/10.3354/dao038081

Morgan, D. L. 1997. Focus groups as qualitative research. SAGE, Vol. 16, Thousand Oaks, California, USA. https://doi. org/10.4135/9781412984287

Moss, M. L., A. T. Rodrigues, C. F. Speller, and D. Y. Yang. 2016. The historical ecology of Pacific herring: tracing Alaska Native use of a forage fish. Journal of Archaeological Science: Reports 8:504-512. https://doi.org/10.1016/j.jasrep.2015.10.005

Mueter, F. J., and B. L. Norcross. 2002. Spatial and temporal patterns in the demersal fish community on the shelf and upper slope regions of the Gulf of Alaska. Fishery Bulletin 100 (3):559-581.

Mundy, P. R. 2005. The Gulf of Alaska: biology and oceanography. Alaska Sea Grant College Program, University of Alaska Fairbanks, Fairbanks, Alaska, USA. https://doi.org/10.4027/ gabo. 2005

Nøttestad, L., and B. E. Axelsen. 1999. Herring schooling manoeuvres in response to killer whale attacks. Canadian Journal of Zoology 77(10):1540-1546. https://doi.org/10.1139/z99-124

Olsson, P., and C. Folke. 2001. Local ecological knowledge and institutional dynamics for ecosystem management: a study of Lake Racken watershed, Sweden. Ecosystems 4(2):85-104. https:// doi.org/10.1007/s100210000061

Palacios-Agundez, I., I. Casado-Arzuaga, I. Madariaga, and M. Onaindia. 2013. The relevance of local participatory scenario planning for ecosystem management policies in the Basque Country, northern Spain. Ecology and Society 18(3):7. https://doi. org/10.5751/ES-05619-180307

Parker, K. S. 1988. Pacific halibut, Hippoglossus stenolepis, in the Gulf of Alaska. Pages 94-111 in N. J. Wilimovsky, L. S. Incze, and S. J. Westrheim, editors. Species synopses: life histories of selected fish and shellfish of the Northeast Pacific and Bering. Washington Sea Grant Program, Seattle, Washington, USA.

Pikitch, E. K., C. Santora, E. A. Babcock, A. Bakun, R. Bonfil, D. O. Conover, P. Dayton, P. Doukakis, D. Fluharty, B. Heneman, E. D. Houde, J. Link, P. A. Livingston, M. Mangel, M. K. 
McAllister, J. Pope, and K. J. Sainsbury. 2004. Ecosystem-based fishery management. Science 305(5682):346-347. https://doi. org/10.1126/science. 1098222

Poe, M. R., J. Donatuto, and T. Satterfield. 2016. "Sense of place": human wellbeing considerations for ecological restoration in Puget Sound. Coastal Management 44(5):409-426. https://doi. org/10.1080/08920753.2016.1208037

Raymond-Yakoubian, J., B. Raymond-Yakoubian, and C. Moncrieff. 2017. The incorporation of traditional knowledge into Alaska federal fisheries management. Marine Policy 78:132-142. https://doi.org/10.1016/j.marpol.2016.12.024

Reum, J. C., P. S. McDonald, B. E. Ferriss, D. M. Farrell, C. J. Harvey, and P. S. Levin. 2015. Qualitative network models in support of ecosystem approaches to bivalve aquaculture. ICES Journal of Marine Science 72(8):2278-2288. https://doi. org/10.1093/icesjms/fsv119

Rohrbach, B., S. Anderson, and P. Laube. 2016. The effects of sample size on data quality in participatory mapping of past land use. Environment and Planning B: Planning and Design 43 (4):681-697. https://doi.org/10.1177/0265813515618578

Rooper, C. N., and L. J. Haldorson. 2000. Consumption of Pacific herring (Clupea pallasi) eggs by greenling (Hexagrammidae) in Prince William Sound, Alaska. Fishery Bulletin 98(3):655-659.

Salter, J., J. Robinson, and A. Wiek. 2010. Participatory methods of integrated assessment-a review. Wiley Interdisciplinary Reviews: Climate Change 1(5):697-717. https://doi.org/10.1002/ wcc. 73

Sharpe, F. A., and L. M. Dill. 1997. The behavior of Pacific herring schools in response to artificial humpback whale bubbles. Canadian Journal of Zoology 75(5):725-730. https://doi. org/10.1139/z97-093

Shaw, W., and T. Hassler. 1989. Species profiles: life histories and environmental requirements of coastal fishes and invertebrates (Pacific Northwest): Lingcod. U.S. Fish and Wildlife Service. Biological Report 82(11.119). U.S. Army Corps of Engineers TR EL-82-4, Vicksburg, Mississippi, USA.

Sill, L. A., and M. Cunningham. 2017. The subsistence harvest of Pacific herring spawn in Sitka Sound, Alaska, 2016. Alaska Department of Fish and Game, Division of Subsistence. Technical Paper 435, Juneau, Alaska, USA.

Sisk, J. 2007. The southeastern Alaska salmon industry: historical overview and current status. Pages 1-15 in J. W. Schoen, and E. Dovichin, editors. The coastal forests and mountains ecoregion of Southeastern Alaska and the Tongass National Forest: a conservation assessment and resource synthesis. Southeast Alaska Conservation Assessment, Anchorage, Alaska, USA.

Sitka Economic Development Association (SEDA). 2017. Sitka, Alaska community profile 2017. SEDA, Sitka, Alaska, USA.

Skud, B. E. 1977. Drift, migration, and intermingling of Pacific halibut stocks. International Pacific Halibut Commission. Scientific Report 63, Seattle, Washington, USA.

Stabeno, P. J., S. Bell, W. Cheng, S. Danielson, N. B. Kachel, and C. W. Mordy. 2016. Long-term observations of Alaska coastal current in the northern Gulf of Alaska. Deep Sea Research Part
II: Topical Studies in Oceanography 132:24-40. https://doi. org/10.1016/j.dsr2.2015.12.016

Stabeno, P. J., N. A. Bond, A. J. Hermann, N. B. Kachel, C. W. Mordy, and J. E. Overland. 2004. Meteorology and oceanography of the Northern Gulf of Alaska. Continental Shelf Research 24 (7-8):859-897. https://doi.org/10.1016/i.csr.2004.02.007

Stevenson, J. C. 1962. Distribution and survival of herring larvae (Clupea pallasi Valenciennes) in British Columbia waters. Journal of the Fisheries Board of Canada 19(5):735-810. https://doi. org/10.1139/f62-049

Strauss, A., and J. M. Corbin. 1990. Basics of qualitative research: grounded theory procedures and techniques. SAGE, Newbury Park, California, USA.

Thornton, T. F. 2015. The ideology and practice of Pacific herring cultivation among the Tlingit and Haida. Human Ecology 43 (2):213-223. https://doi.org/10.1007/s10745-015-9736-2

Thornton, T. F., and H. Kitka. 2015. An indigenous model of a contested Pacific herring fishery in Sitka, Alaska. International Journal of Applied Geospatial Research 6(1):94-117. https://doi. org/10.4018/ijagr.2015010106

Thornton, T. F., M. L. Moss, V. L. Butler, J. Hebert, and F. Funk. 2010. Local and traditional knowledge and the historical ecology of Pacific herring in Alaska. Journal of Ecological Anthropology 14(1):81-88. https://doi.org/10.5038/2162-4593.14.1.7

Tremblay, M.-A. 1957. The key informant technique: a nonethnographic application. American Anthropologist 59 (4):688-701. https://doi.org/10.1522/030608642

Wadsworth, R. M., K. Criddle, and G. H. Kruse. 2014. Incorporating stakeholder input into marine research priorities for the Aleutian Islands. Ocean and Coastal Management 98:11-19. https://doi.org/10.1016/j.ocecoaman.2014.06.003

Weingartner, T., L. Eisner, G. L. Eckert, and S. Danielson. 2009. Southeast Alaska: oceanographic habitats and linkages. Journal of Biogeography 36(3):387-400. https://doi.org/10.1111/ j.1365-2699.2008.01994.X

Whitney, F. A., W. R. Crawford, and P. J. Harrison. 2005. Physical processes that enhance nutrient transport and primary productivity in the coastal and open ocean of the subarctic NE Pacific. Deep Sea Research Part II: Topical Studies in Oceanography 52(5-6):681-706. https://doi.org/10.1016/j.dsr2.2004.12.023

Wilkinson, S. 1998. Focus groups in health research: exploring the meanings of health and illness. Journal of Health Psychology 3(3):329-348. https://doi.org/10.1177/135910539800300304

Wolfe, R. J. 2004. Local traditions and subsistence: a synopsis from twenty-five years of research by the State of Alaska. Alaska Department of Fish and Game, Division of Subsistence, Juneau, Alaska, USA.

Zador, S. G., S. K. Gaichas, S. Kasperski, C. L. Ward, R. E. Blake, N. C. Ban, A. Himes-Cornell, and J. Z. Koehn. 2017. Linking ecosystem processes to communities of practice through commercially fished species in the Gulf of Alaska. ICES Journal of Marine Science 74(7):2024-2033. https://doi.org/10.1093/ icesjms/fsx054 
Appendix 1. Documented key factors within and linkages among biological model components for focal species. From the available scientific literature, a link direction (i.e., positive, negative, or unknown) and a link description (i.e., summary of the interaction) were recorded. 
Ecology and Society 24(3): 30 https://www.ecologyandsociety.org/vol24/iss3/art30/

Appendix 2. Documented key factors within and linkages among environmental model components for focal species. From the available scientific literature, a link direction (i.e., positive, negative, or unknown) and a link description (i.e., summary of the interaction) were recorded. 


\section{Appendix 3}

Ecosystem representations for outreaching purposes. Reproduced with permission of NOAA fisheries.

\section{Halibut Social-Ecological Conceptual Model}

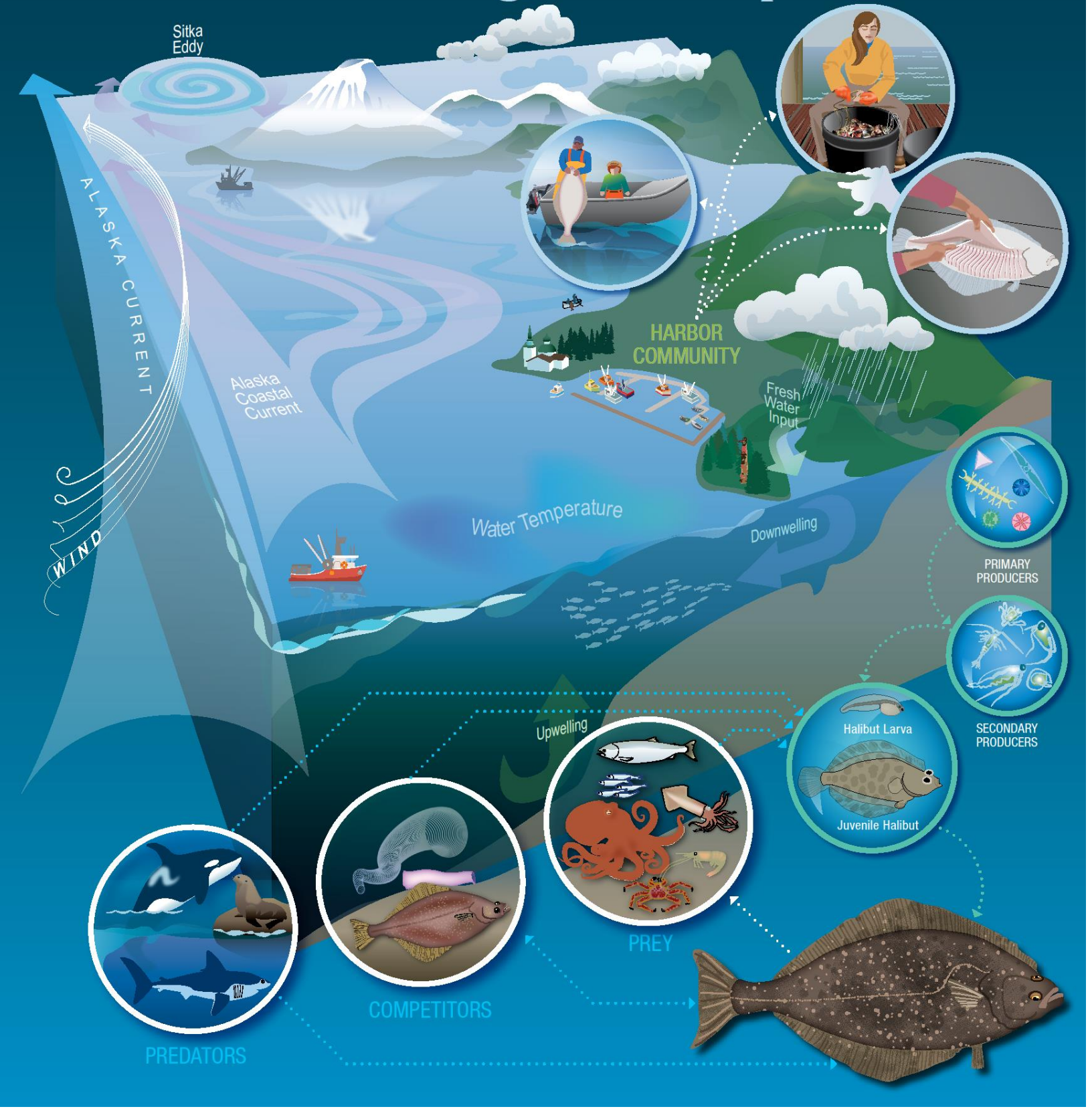




\section{Herring Social-Ecological Conceptual Model}

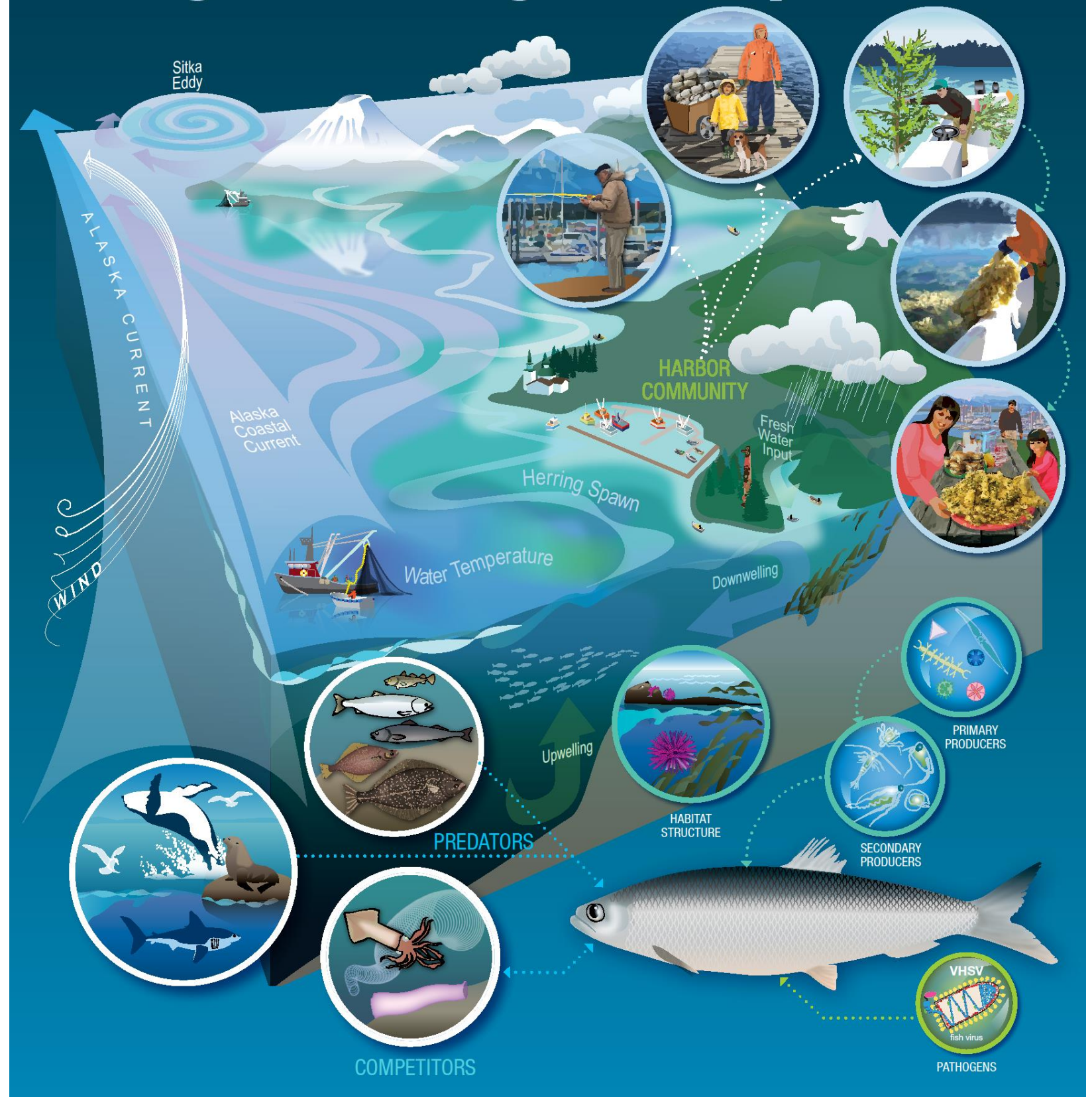

